\title{
OBITUARY
}

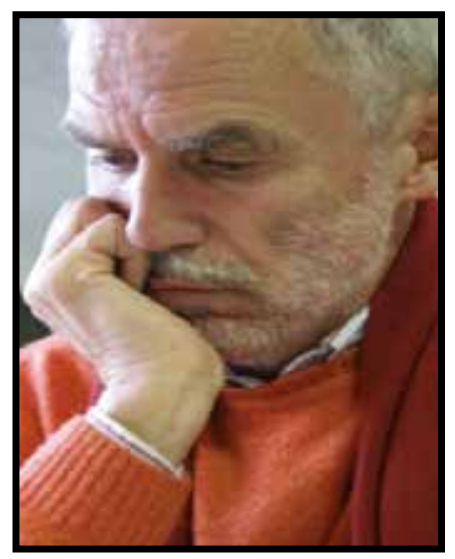

\section{Henk Haisma}

\section{(12 Februaty1949 - 25 December 2019)}

It is with great sadness that we learn of Henk's untimely death.

Henk Haisma was a Dutch anesthesiologist of the highest order. During the late 1990s and early 2000s he was pivotal in the early growth and development of Primary Trauma Care (PTC). PTC was, in fact, his second love after anesthesiology.

His spent a lot of his time and efforts in Africa to bring a fresh and vibrant perspective in the work of the WFSA and PTC in Southern, East and West Africa. His interest in working with all peoples equally and fairly was not restricted to Africa only, rather it also took him to Indonesia and South America and through these connections Henk was able to promote PTC and good clinical care and trauma training to thousands of people across the world.

Henk was a crazy chess player, and he remained the backbone of the local National chess club, and remained a national champion. After spending decades of very hectic life, during his final years he settled in Holland to enjoy peace and some rest. His humor, drive and compassion reached to all of his fellow workers across the continents. He is survived by his wife Rommy, his daughter and grandson and his passion for chess.

His unexpected death is felt by us all and we pay tribute to Henk and his family for their vast contribution to health care worldwide.

DOI: https://doi.org/10.35975/apic.v24i1.1242 